\title{
CAM 操作者の意図を考慮したエンドミル加エ用自動エ程設計システム
}

\author{
西田 勇 $^{* 1}$, 平井 大志 ${ }^{* 2}$, 佐藤 隆太 ${ }^{* 1}$, 白瀬 敬一 ${ }^{* 3}$
}

\section{Automatic process planning system for end-milling operation considering CAM operator's intention}

\author{
Isamu NISHIDA*1 $^{* 1}$, Taishi HIRAI ${ }^{* 2}$, Ryuta SATO*1 and Keiichi SHIRASE ${ }^{* 3}$

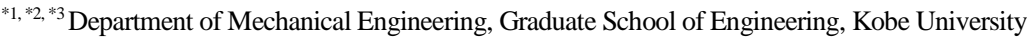 \\ 1-1 Rokko-dai, Nada-ku, Kobe, Hyogo 657-8501, Japan
}

Received: 7 December 2017; Revised: 14 January 2018; Accepted: 18 March 2018

\begin{abstract}
In this study, an automatic process planning system for end-milling operation is proposed, in which CAM operator's intention for process planning is considered. In the previous process planning systems, the machining sequence is calculated geometrically, based on the Total Removal Volume (TRV) and the machining region split from TRV. However, it remains difficult to determine the best machining sequence from the large number of the calculated machining sequences. The previous process planning systems also do not consider CAM operator's intention in the determination of the appropriate machining sequence. First, our new process planning system stores the priority of machining feature and the geometrical properties of the selected machining region when a CAM operator decides the machining sequence. After storing the priority of machining feature and the geometrical properties, the appropriate machining sequence can be automatically determined by referring this information. CAM operator's intention, which is involved implicitly in the stored geometrical properties of the machining region, can be applied to decide machining sequence. A case study was conducted to show the effectiveness of our new proposed process planning system. In the case study, user-specific machining sequences were automatically determined based on the implicit relation among the geometrical properties of the machining region and the individual CAM operator's intention.
\end{abstract}

Keywords : Process planning, CAM operator's intention, End-milling, Customization

\section{1. 緒言}

現在，コンピュータによる数值制御で自動運転を行う NC工作機械は世界中で広く普及しており，必要となる 部品形状を高精度に高効率で加工できることから，多くの製造現場で利用されている．NC工作機械は NC プロ グラムとよばれる数值制御プログラムを用いて駆動されるため， NC プログラムの作成を支援する CAD/CAM な どのソフトウェアが急速に発展してきた．しかしながら，市販されている CAM ソフトウェアでは，加工領域の 選択や加工順序の決定，加工条件の決定など膨大な作業が使用者に求められている。一方で，顧客要求の急激な 変化と市場二ーズの多様化に伴い，生産形態は多品種少量生産，多品種一品生産へと移行し，生産現場ではより 効率的な生産システムが求められている．NC 工作機械による機械加工においては，製品ごとに NCプログラム の作成が必要となるため，段取り作業時間が膨大になるといった問題がある。そこで，生産リードタイムにおけ る段取り作業時間を短縮するために，従来は作業者が行っていた工程設計をコンピュータで代替する工程設計支 援システムの開発が求められている。 これまでに工程設計支援システムに関する多くの研究がなされている. こ れまでの研究では，目標形状から加工フィーチャと呼ばれる加工工程を特徵付ける領域を認識付けるのが一般的

No.17-00563 [DOI: 10.1299/transjsme.17-00563], J-STAGE Advance Publication date : 2 April, 2018

*1 正員，神戸大学大学院工学研究科（广 657-8501 兵庫県神戸市灘区六甲台町 1-1）

*2 学生員, 神戸大学大学院工学研究科

*3 正員, フェロー, 神戸大学大学院工学研究科

E-mail of corresponding author: nishida@mech.kobe-u.ac.jp 
であり（杉村，2006），様々な加工フィーチャ認識方法が提案されている. 加工フィーチャの認識において，目標 形状を基に加工フィーチャの認識を行っている方法 (濱田他, 2012, Wang et al., 2010, Woo et al., 2005, El-Mehalawi et al., 2003a, 2003b）が提案されている. しかしながら，本来は目標形状でなく除去形状から加工フィーチャを認 識すべきであり，これまでに除去領域を対象にして加工フィーチャを認識する方法（上野，中本，2015，Morinaga et al., 2011, 2014, Dwijayanti and Aoyama，2014, Sakurai and Dave，1995，1996，井上，中本，2017，西田他，2017） が提案されている.これらの中でも, 著者らはエンドミル加工用の工程設計の自動化に向けて, 除去領域を順次 分割して加工順序を導出する際に，分割面に制約を設けず，なおかつ除去領域の分割面の数が過剰になることを 解消し，5軸割り出し加工を考慮した加工順序を導出する方法を提案している（西田他，2017）.

しかしながら，これまでの工程設計の自動化に関する研究では，導出される加工工程案は複数存在し，複数の 加工工程案の中から実加工で使用するための加工工程を 1 選択する必要があるが，その選択には加工時間が最 短となる工程や工具経路が最短となる工程を最適工程として導出している場合が多い. このように実加工で使用 するための加工工程の選択において，アルゴリズムに依存した既存のシステムでは常に同じ判断基準で決定され るため, 得られる加工工程に多様性がなくなり, 企業や工場の競争力が発揮できないという課題があつた. また, 既存のシステムで得られる加工順序が加工現場の意図と異なる場合に適応が難しいといった課題があった.

そこで本研究では, CAM 操作者の加工ノウハウを学習して, CAM 操作者が意図する加工領域および加工順序 を自動で導出可能な工程設計システムを開発することを目的とする. 開発するシステムでは, 加工フィーチャに 基づいた工程設計に従って, CAM 操作者がシステムと対話形式で操作を行う際に教示する情報から加工優先度 の特徵を解析して蓄積する. そして, CAM 操作者の加工ノウハウを学習した情報に基づいて工程設計を行うこ とで，CAM 操作者の意図を考慮した加工順序を自動で導出することが可能となる.

\section{CAM 操作者の意図を考慮した自動エ程設計システム}

本研究では, 機械加工の自動化に必要な NC プログラムの作成において, CAM 操作者の加工ノウハウを学習し て, CAM 操作者が意図する加工領域および加工順序を自動で導出可能な工程設計システムを構築する. 本シス テムの特徴は, CAM 操作者の加工ノウハウを学習して加工順序の決定に反映させる点であり, 操作する CAM 操 作者が違えば学習する加工ノウハウが異なり, それに対応して決定される加工順序も異なる点である. アルゴリ ズムに依存した既存のシステムでは常に同じ判断基準で加工順序が決定されるため, 作成される NCプログラム に多様性がなくなり，企業や工場の競争力が発揮できないという課題があった．また，既存のシステムで得られ る加工順序が加工現場の意図と異なる場合に適応が難しいといった課題があった．本システムでは CAM 操作者 の意図を反映した個性的な加工順序を自動で導出することができるので，競争力の高い機械加工を高効率で実現 することができる. 本システムでは CAM 操作者の操作履歴に潜むデータを収集・蓄積し, それを分析して加工 ノウハウを学習する. 本システムの構成を図 1 に示す. 本システムは次の 3 つの要素から成る. 1 つ目は加工除 去領域の抽出および分割, 2つ目は加工優先度の教示および学習, 3 つ目は加工順序の自動決定である. 本研究で は, Visual Studio 2015 にてプログラムを作成し(使用言語:C\#), SolidWorks 2015 の API 機能を使用して SolidWorks 上で CAD モデルの解析を行うことで本システムを構築している.

\section{$2 \cdot 1$ 加工除去領域の抽出および分割}

加工除去領域の抽出および分割においては, 著者らが提案している方法 (西田他, 2017) を用いて解析を行う. まず，被削材形状と製品形状の差分の領域である総加工除去領域（Total Removal Volume: TRV）を抽出する. $\mathrm{TRV}$ を用いる理由としては, 製品形状が同じでも被削材形状が異なる場合は除去領域が異なるために,加工領域お よび加工順序が同じであるとは限らないためである.また，加工中にトラブルが発生するなどして加工が中断し た被削材に対して, 再度加工順序を決定し直すことが可能となり, 生産システムの柔軟性の向上が期待できるた めである. CAD 上で被削材形状と製品形状のソリッドモデルから，抽出された TRV の例を図 2 に示す.

次に, 抽出された TRV を構成する平面で分割して, 分割加工除去領域 (Split Removal Volume: SRV) を抽出す る.ここで，抽出された TRV を構成する平面で分割する理由としては，抽出された TRV の形状はコンピュータ がその形状の特徵を判別するには複雑であるため, 多角柱や円柱などのコンピュータが容易に判別可能な形状に 


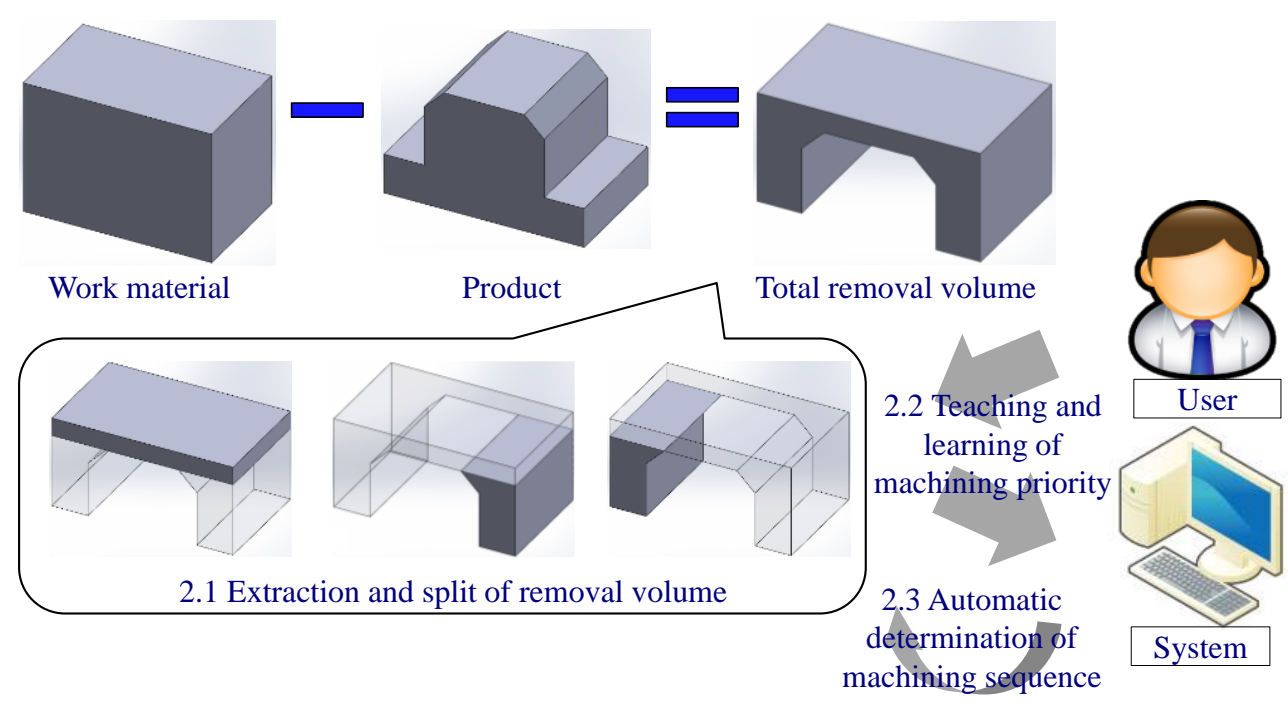

Fig. 1 Configuration of the proposed system, which consists of extraction and split of removal volume, teaching and learning of machining priority and automatic determination of machining sequence

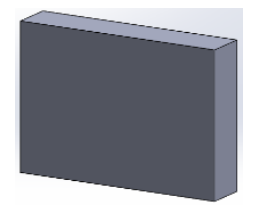

(a) Work material

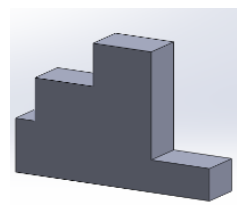

(b) Product

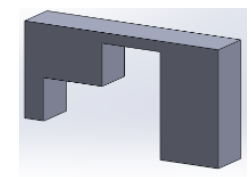

(c) TRV

Fig. 2 Example of total removal volume extracted from work material and product shapes by Boolean operation

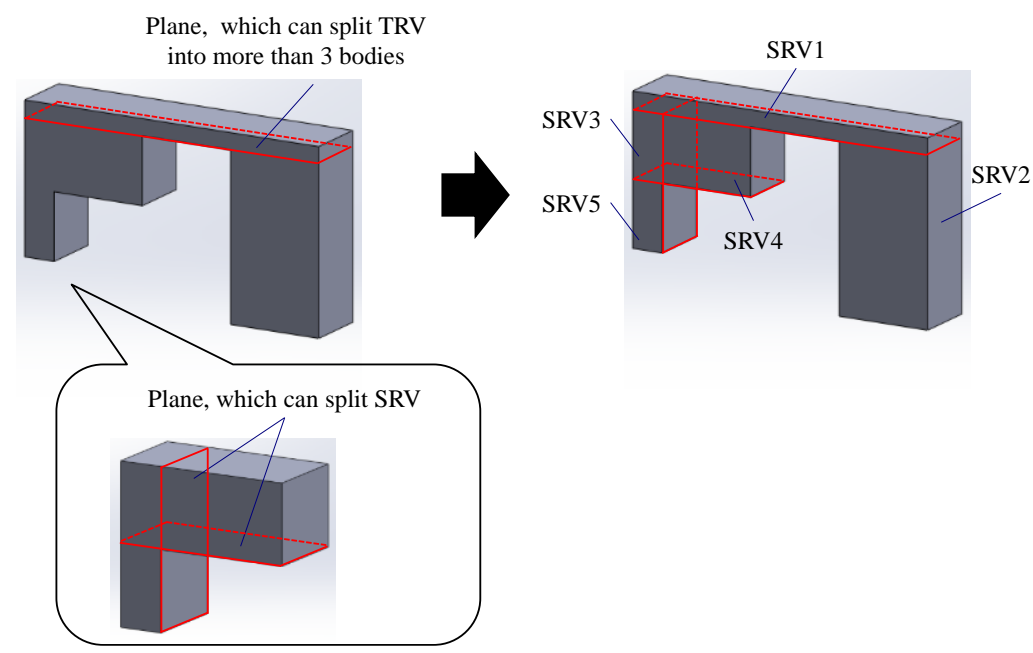

Fig. 3 Example of split removal volume extracted by splitting the extracted TRV on the plane, which can split the TRV into more than 3 bodies, and the composed surface planes

て解析を行うためである．ここでは，分割面の数が過剩になることを解消するために，実加工に適した平面を選 択して分割している. まず，抽出された TRVに対して，TRV が有する平面を探索し，その平面で分割した場合 に，3つ以上の要素に分割可能な平面を探索し，その平面で分割して SRV を抽出する. 抽出された SRV に対し て, さらに 3 つ上のボディに分割可能な平面が存在する場合は, 再度分割を行う。この操作を 3 つ上小ボデ イに分割ができなくなるまで繰り返す，最後に，抽出された SRVにおいて，SRV を構成する平面で分割が可能 である場合は，SRVをさらに分割する．図３にSRV を抽出するための TRVの分割平面の例を示す. 


\section{$2 \cdot 2$ 加工優先度の教示および学習}

ここでは, CAM 操作者の加工ノウハウを学習するために, CAM 操作者がシステムと対話形式で操作を行う際 に教示する情報から加工優先度を決定する特徵を収集，解析および蓄積する方法について述べる.

取得した分割加工除去領域 SRV に対して，除去順序を決定することで，加工順序を導出することができる．従 来の加工順序決定方法（西田他, 2017）では, 抽出された SRV に対して, 大気に触れている面（オープンフェイ ス）の数より加工順序を決定していた. しかし，この方法では，工具がアプローチできる方向の多さという基準 のみで加工優先度を判断している. そのため, 例えばドリル穴加工（オープンフェイスの数が 1）と溝加工（オ ープンフェイスの数が 3）が存在している場合には, 必ず溝加工が優先されていた. しかしながら, ドリル穴加 工と溝加工が存在している場合に必ず溝加工を優先して行うとは限らない. そこで, 本研究ではオープンフェイ スの数のみで加工優先度を判断するのではなく, 加工除去領域の特徴を考慮できる加工フィーチャに基づいて加 工優先度を判断する. ここで, 加工フィーチャとは, 加工除去領域に対して加工工程を特徴付けるものである. 本研究では図 4 に示寸ような 9 つの加工フィーチャを用いて解析を行った. 図 4 に示寸加工フィーチャは除去領 域のオープンフェイスの数および工具アプローチ面の形状によって自動で判別することができる.

抽出された各 SRV の加工フィーチャを認識し, 加工を優先する加工フィーチャを CAM 操作者が選択し, 加工 順序を教示する. 例えば, 図 5(a)に示すような製品形状を加工する場合, 加工除去領域の加工フィーチャは Step, Closed Pocket および Through hole と認識できる.このとき，CAM 操作者はどの加工フィーチャを優先して加工 したいかを対話形式でシステムに入力することで, システムは加工フィーチャの加工優先度を学習する.例えば, CAM 操作者が Closed pocket, Step, Through hole の順での加工を選択した場合, 図 5(b)のような総当たり表が作 成できる. 本システムを使用していく中で CAM 操作者からの教示が十分に行われると, 9 つの加工フィーチャ に対して総当たり表が作成でき, 教示した CAM 操作者の判断に基づいた加工フィーチャの加工優先度の情報が 生成される.

次に, 加工フィーチャでの加工優先度が同じ SRV が複数存在する場合は, その中で加工優先度を決定する必要 がある．例えば，図 6 に示寸製品形状の除去領域 SRV1, SRV2 の Step について, CAM 操作者はどちらの領域を 優先して加工したいかを対話形式でシステムに入力する. このとき，CAM 操作者は加工する順番のみを入力す るが, CAM 操作者は独自の判断基準に従って加工順序を決定している. しかしながら, この判断基準を明確に 表現することは難しく, CAM 操作者の加工ノウハウに従っていることが多い. そこで, 本研究では CAM 操作者 が教示した加工順序について, 加工領域の幾何情報に着目することで, CAM 操作者の加工順序決定における傾 向を解析する．例えば図 6 において, CAM 操作者が SRV1, SRV2 の順での加工を選択した場合, 2 つの除去領 域の幾何情報を相対的に比較すると, 体積は小さい領域の加工を優先し, 位置は X 座標の小さい領域の加工を優 先し, 加工深さは浅い領域の加工を優先するという情報を得ることができる. 本研究では, 加工領域の幾何情報

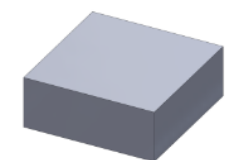

Face

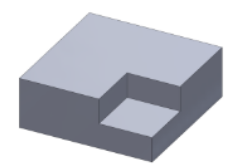

Open pocket

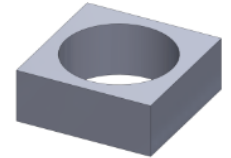

Through hole

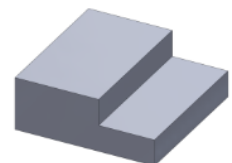

Step

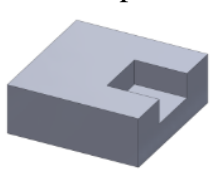

Closed slot

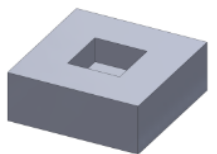

Closed pocket

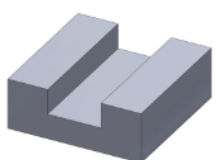

Open slot

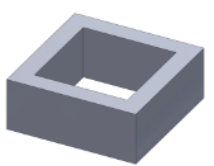

Through pocket

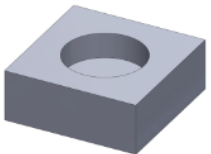

Blind hole

Fig. 4 Machining features which this study considers. Machining feature is recognized from the number of the open face of the machining region and the shape of the tool-approaching surface. 


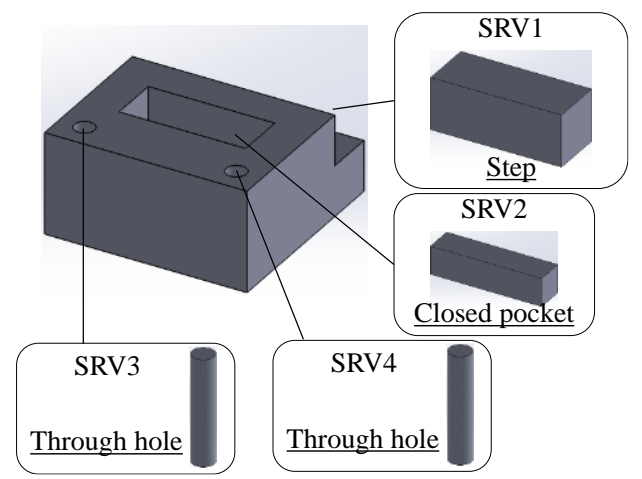

Fig. 5a Example of the machining feature recognition, in which step, closed pocket and through hole are recognized

\begin{tabular}{|l|c|c|c|c|}
\hline & Step & Closed pocket & Through hole & $\cdots$ \\
\hline Step & & $\times$ & 0 & $\cdots$ \\
\hline Closed pocket & O & & 0 & $\cdots$ \\
\hline Through hole & $\times$ & $\times$ & & $\cdots$ \\
\hline$\quad \vdots$ & $\vdots$ & $\vdots$ & $\vdots$ & \\
\hline
\end{tabular}

Fig. 5b Example of the obtained round-robin table, in which the order of the machining priority is closed pocket, step, through hole

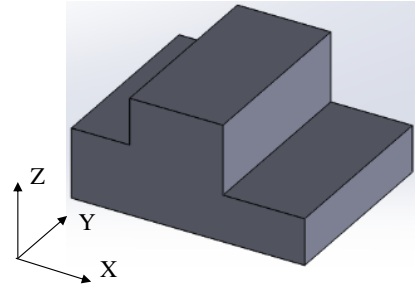

(a) Product
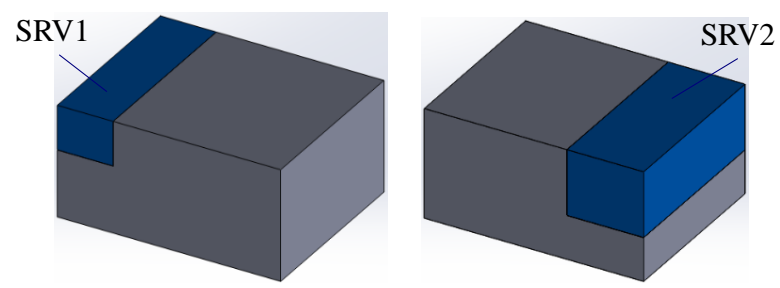

(b) Extracted split removal volume for determination of machining sequence

Fig. 6 Example for the determination of the machining priority depending on the geometric information (The volume of SRV1 is smaller than that of SRV2. The X-coordinate position of SRV1 is lower than that of SRV2. The depth of SRV1 is shallower than that of SRV2.)

Table 1 Categories for the collection of the geometrical properties

\begin{tabular}{|c|c||c|c|}
\hline \multicolumn{1}{|c||}{ Category } & \multicolumn{2}{c|}{ Geometrical property } \\
\hline \hline \multicolumn{2}{|c|}{ Volume } & Large & Small \\
\hline \multirow{3}{*}{ Position } & X-coordinate & High & Low \\
\cline { 2 - 4 } & Y-coordinate & High & Low \\
\cline { 2 - 4 } & Z-coordinate & High & Low \\
\cline { 2 - 4 } & Depth & Deep & Shallow \\
\hline \multicolumn{2}{|c|}{ Distance } & Far & Near \\
\hline \multicolumn{2}{|c|}{ Inside and outside } & Inside & Outside \\
\hline
\end{tabular}

として表 1 に示す 5 つの項目を定義して，解析を行う．定義した 5 つの項目は体積（Volume）, CAD 座標系での 位置 (Position), 加工染さ (Depth), 前工程との距離 (Distance), 加工対象の中心からの相対位置 (Inside and outside) である，それぞれの項目には相対情報を示寸属性を設けている。ここでは，工程設計の段階における CAD モデ ルの解析にて幾何情報を取得するため, CAD 座標系での情報を用いている. CAM 操作者が加工順序を対話形式 でシステムに入力するたびに，候補となっている除去領域の幾何情報を計算して相対的な比較を行い，加工順位 が高い除去領域に該当する幾何情報の属性のスコアに加算する. 本システムを使用していく中で CAM 操作者 からの教示が十分行われると，加工領域の幾何情報として定義したそれぞれの項目において，どちらの加工を優 先する傾向があるかを取得することができる.

上記のように，加工除去領域の幾何情報に着目して，幾何情報の相対的な比較によって CAM 操作者の加工順 序決定における傾向を解析する方法を提案しているが，加工順序を決定する領域の候補が多い場合は，相対的な 比較のみで CAM 操作者の加工順序決定における傾向を解析することは困難である．例えば，図 7(a)に示すよう な穴加工を連続して行う場合, 候補が多いため, 幾何情報の相対的な比較では CAM 操作者の加工順序決定にお 
ける傾向を正しく取得することができない，そこで，本研究では穴加工を連続して行う場合のように同じ形状の 除去領域が複数存在する場合には，除去パターンと加工開始位置の情報に着目して解析を行う．除去パターンと 加工開始位置の情報には表 2 に示寸属性を定義している. 除去パターンには直線パターン，ジグザグパターン， スパイラルパターンを定義している．また，加工開始位置として，工具アプローチ平面での相対座標におけるX 座標および Y 座標の相対位置を定義している. 除去パターンは, CAM 操作者が教示した加工順序に対して, 加 工領域の工具アプローチ面の中心を結ぶベクトルの向きの変化から判別している. 図 7(b)に示すように, 直線パ ターンではベクトルの向きに 90 度を超えるような大きな変化があり, そのような変化の数が多いことから判別で きる. ジグザグパターンではベクトルの向きの変化が小さいものが多く, 変化する向きがすべて同じことから判 別できる. スパイラルパターンでは, ベクトルの向きの変化が小さいものが多く, 変化する向きがすべて同じで ないことから判別できる.

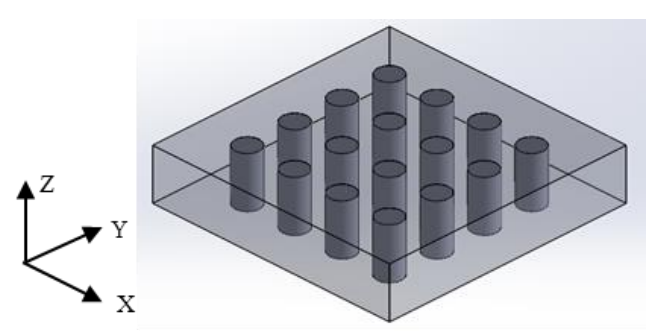

Fig.7a Example of the extracted SRV, in which a lot of SRV of the same shape exists. It is difficult to obtain the user's intention for the machining sequence determination by the relative comparison of the geometric information.

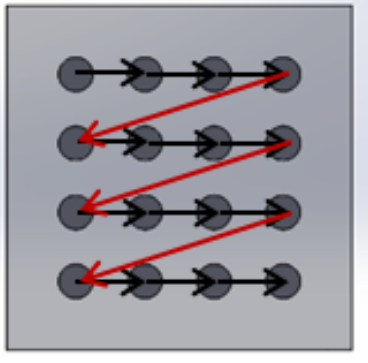

(a) Liner pattern

$\longrightarrow$ : Vector, the direction of which changes greatly $\rightarrow$ : Vector. The direction of which changes small

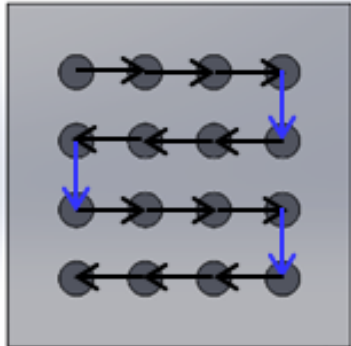

(b) Zigzag pattern

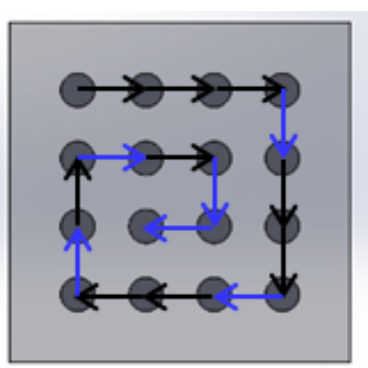

(c) Spiral pattern

Fig.7b Machining sequence pattern when there are a lot of SRV of the same shape. The machining sequence pattern is determined by the vector connecting the SRV. In liner pattern, there are some vectors, the direction of which changes greatly. In zigzag pattern, there are some vectors, the direction of which changes small and the direction of the vector is same. In spiral pattern, there are some vectors, the direction of which changes small and the direction of the vector is different.

Table 2 Categories for the collection of the machining sequence pattern and the first machining position

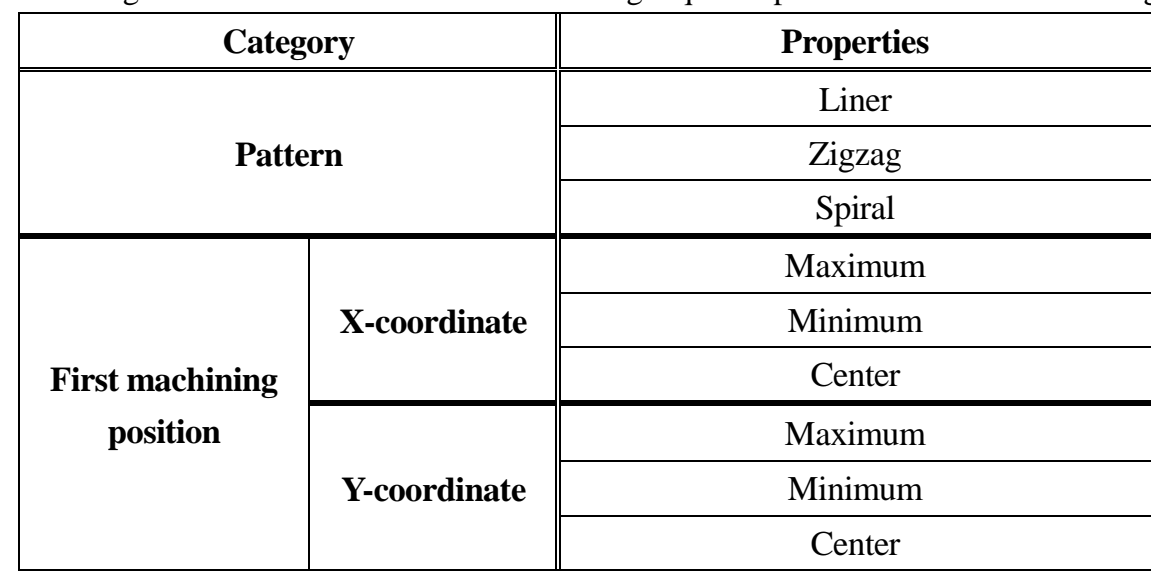


このように, CAM 操作者が本システムと対話形式で加工フィーチャの加工優先度および加工順序を入力する だけで, その CAM 操作者の加工順序決定における傾向を解析し，加工順序を決定する際の判断基準として蓄積 することができる．ここで加工順序を決定する際の判断基準に関する情報は使用する CAM 操作者ごとにそれぞ れ蓄積するが，CAM 操作者が同じでも使用寸る工作機械や被削材などが異なれば，その判断基準が異なること が考えられる. そのため，CAM 操作者が同じでも使用する工作機械や被削材などの加工条件ごとに判断基準を 蓄積することもできる.

\section{$2 \cdot 3$ 加工順序の自動決定}

CAM 操作者が本システムと対話形式で加工フィーチャの加工優先度および加工順序を入力し, CAM 操作者か らの教示が十分行われると, 蓄積した情報を用いて CAM 操作者の意図を考慮した加工順序の自動決定が可能と なる.

まず，抽出された各 SRV に対して，加工フィーチャを認識する. 認識した加工フィーチャにおいて，図 5(b) に示した総当たり表を参照することで，加工優先度を決定することができる．例えば，図 5(a)の製品形状を解析 する場合, 加工除去領域の加工フィーチャは Step, Closed Pocket およびThrough hole と認識できる. このとき, 総当たり表を参照すると, Step は Closed pocketより加工優先度が低く, Through holeより加工優先度が高いこと が決まる．同様に, Closed pocket は Step および Through holeより加工優先度が高く, Through hole は Step および Closed pocketより加工優先度が低いことが決まるため, Closed pocket, Step, Through hole の順で加工することが 自動で決定できる. 総当たり表の情報が変われば, 当然加工フィーチャの加工優先度も変わるため, 蓄積した情 報に基づいた加工順序を決定することができる．

次に, 加工フィーチャでの加工優先度が同じ複数の SRV に対して, 表 1 に示した加工領域の幾何情報を参照す ることで, 加工順序を決定することができる. 本研究では, 蓄積した幾何情報の属性のスコアから各 SRV の加工 優先度の重みを算出寸る.この重みは CAM 操作者が加工順序を教示寸る際に幾何情報の各項目の属性に蓄積さ れるスコアを標準化し, 加算して求める. 例えば, 図 8(a)に示すような幾何情報の属性のスコアを用いて, 図 8(b) の加工領域を解析する場合に, 加工順序は SRV2, SRV1 の順に自動で決定することができる. SRV1 およびSRV2 の幾何情報を比較すると, SRV2 は SRV1 に比べて体積（Volume）が大きく, X座標位置（Position）が大きく, 加工深さ（Depth）が深いことが得られる。ここで, SRV2の重みは, 蓄積した加工領域の幾何情報を参照し, 体 積（Volume）の大きい属性の重み，X座標位置（Position）の大きい属性の重みおよび加工深さ（Depth）の深い 属性の重みの合計となる，同様にSRV1の重みは体積（Volume）の小さい属性の重み，X座標位置（Position）の 小さい属性の重みおよび加工深さ（Depth）の浅い属性の重みの合計となる. 重みの大小によって加工優先度を決 定することができるため, 加工順序が決定する. ここで, 使用する加工領域の幾何情報が変われば, 当然 SRV の 加工優先度も変わるため, 蓄積した情報に基づいた加工順序を決定することができる.

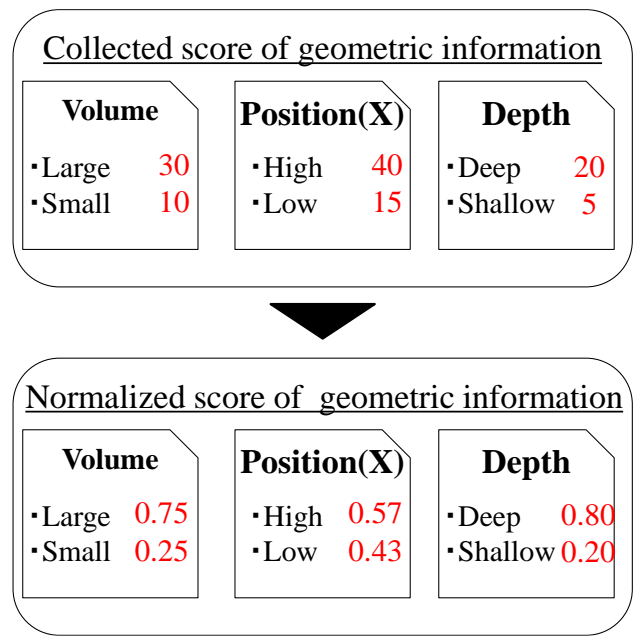

(a) Collected score of geometric information and calculated normalized score
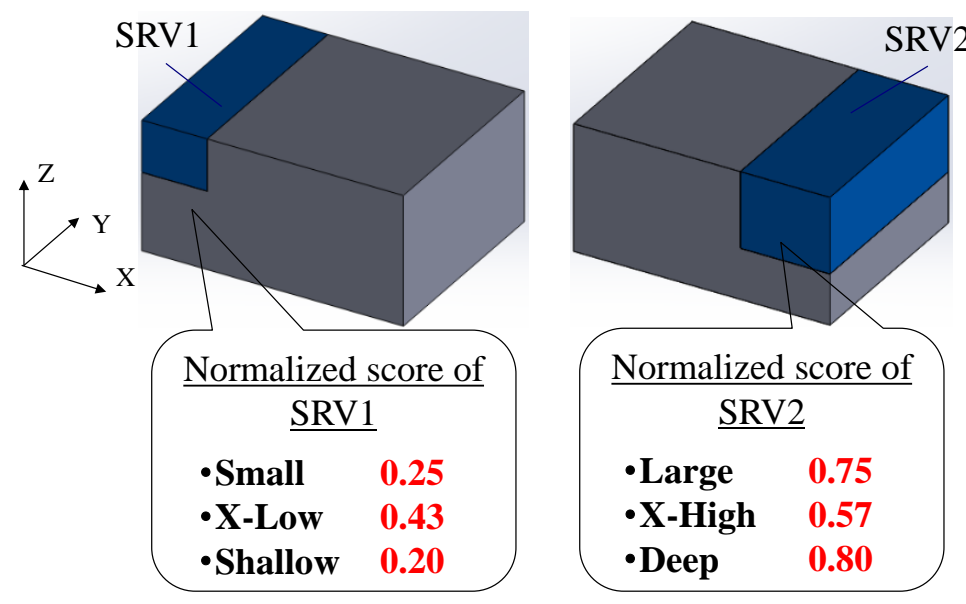

(b) Comparing the sum of normalized score between SRV1 and SRV2 for the determination of the machining sequence

Fig.8 Example of the automatic machining sequence determination depending on the geometric information 
また，図 7(a)に示したような穴加工を連続して行う場合のように同じ形状の除去領域が複数存在する場合も同 様にして, 蓄積した情報を参照することで, 除去パターンと加工開始位置を自動で決定できるため, 蓄積した情 報に基づいた加工順序を決定することができる.

\section{3. ケーススタディ}

本研究で提案した自動工程設計システムの有用性を確認するために, ケーススタディを実施した. ケーススタ ディでは, 図 9 に示寸 3 つの製品形状を用いる. これらのモデル対して後述する意図の異なる 2 通りの加工順序 を用意し, モデル 1 およびモデル 2 の加工順序を本システムに対話形式で教示した. そして, モデル 3 に対して, 得られた 2 通りの学習データを用いて, 自動で工程設計を行い, それぞれの意図と同じ加工順序が得られるかど うかを検証した。

まず，モデル 1 およびモデル 2 に対して，予め用意した加工順序を本システムに対話形式で教示した．それぞ れのモデルから取得される加工除去領域とその加工フィーチャおよび教示した 2 通りの加工順序について, モデ ル 1 を図 10 に，モデル 2 を図 11 にそれぞれ示す. また, 教示して得られた加工フィーチャの優先度情報および 幾何情報の属性のスコアを, モデル 1 およびモデル 2 を用いて加工順序 1 を教示した場合の結果を表 3 に, 加工 順序 2 を教示した場合の結果を表 4 にそれぞれ示寸，ここで，加工順序 1 で，ドリル加工である Through hole や Blind hole を優先して加工し, 次に被削材のひずみを考慮して被削材の中心に近く, 除去体積の大きい Closed pocket を加工し, 最後にClosed slot を加工するという意図を含んだ加工順序となっている. 一方, 加工順序 2 で は, 加工が難しい Closed pocket から加工を行い, 次に加工の効率を考慮して, 同じ工具で加工が可能な Closed slot を加工し，最後にドリル加工である Through hole を加工するという意図を含んだ加工順序となっている.また， 加工領域の幾何情報について, 加工順序 1 では, ドリル加工である Through hole や Blind hole を加工する際, Y 座標位置が小さい領域を優先して加工するという意図を含んだ加工順序となっている. 一方, 加工順序 2 では, Y 座標位置が大きい領域を優先して加工寸るという意図を含んだ加工順序となっている．これらの加工順序およ び意図については，実際に機械加工業務に従事している技能者にアンケートを行って得たものである.

次に, モデル 1 およびモデル 2 の加工順序を教示して得られた 2 通りの学習データを用いて工程設計を自動で 行った. モデル 3 における加工除去領域およびその加工フィーチャを図 12 に示寸. 加工順序 1 を教示して得られ た情報に基づいて, 自動で加工順序を決定した結果を図 13a に示寸.図 13a の結果では, ドリル加工である Through hole を優先して加工し, Y 座標位置が小さい領域の Through hole を優先して加工する加工順序が得られており, CAM 操作者の意図を反映したものとなっている. また, 同様に加工順序 2 を教示して得られた情報に基づいて, 自動で加工順序を決定した結果を図 13bに示寸. 図 13b の結果では, ドリル加工である Through holeを最後に加 工し, Y 座標位置が大きい領域の Through hole を優先して加工する加工順序が得られており, CAM 操作者の意図 を反映したものとなっている. ケーススタディの結果として, 学習した情報に基づいて CAM 操作者の意図を考 慮した加工順序を自動で決定できることが確認できた。ささらに，ケーススタディの結果から使用する情報が異な ると導出される加工順序も異なることが確認できた. 本ケーススタディに用いたモデル 3 において, 加工順序は 全部で 120 (5!) 通り存在する. それらの複数の加工順序の候補から CAM 操作者が選択した加工順序と同じもの を自動で決定できることが確認できた.

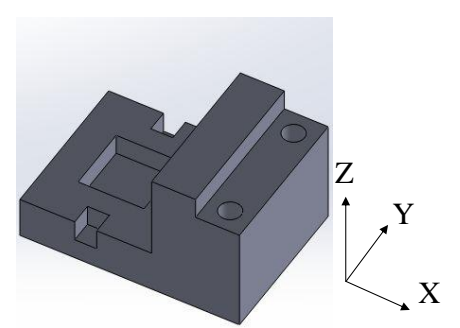

(a) Model 1

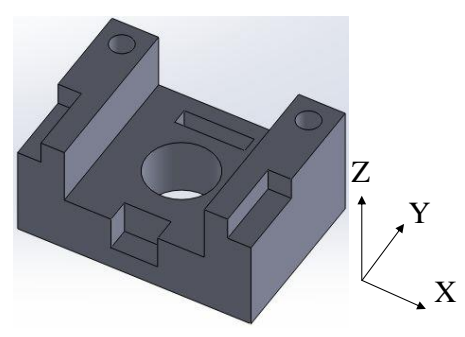

(b) Model 2

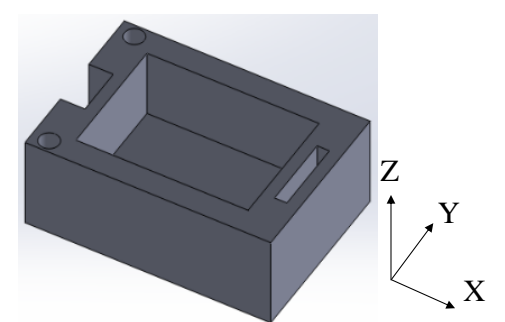

(c) Model 3

Fig.9 Input data for case study. Model 1 and Model 2 are the learning data. Model 3 is the verification data. 


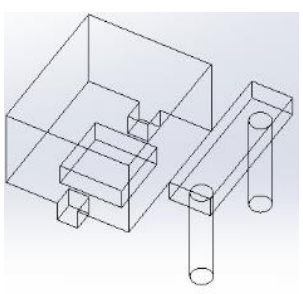

Removal volume

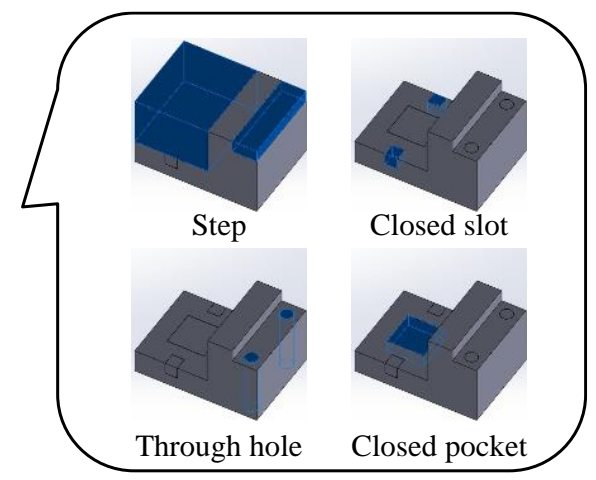

(a) Removal volume and machining feature extracted from the work material and the product shape

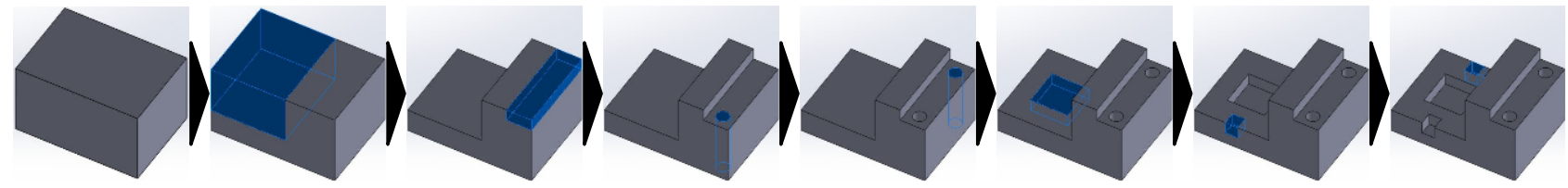

(b) Machining sequence 1

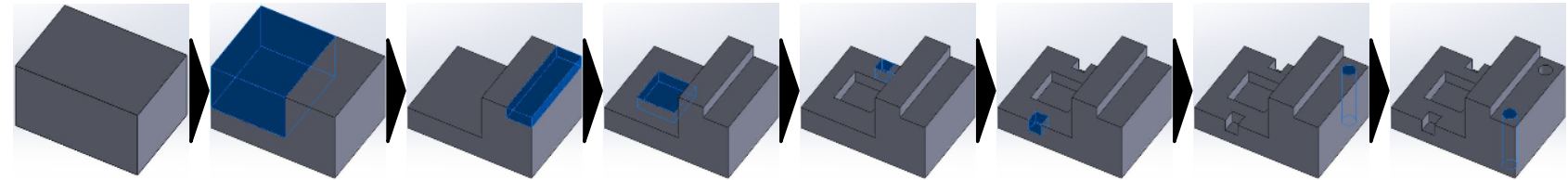

(c) Machining sequence 2

Fig. 10 Removal volume, machining feature and 2 patterns of machining sequence, the intention of which is different, of Model 1

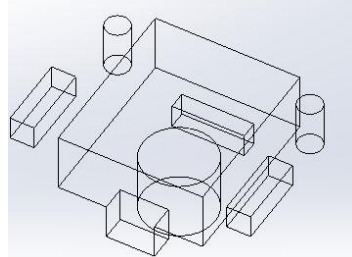

Removal volume

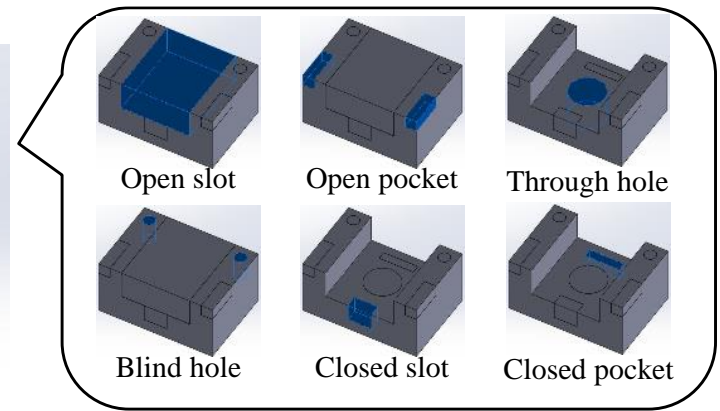

(a) Removal volume and machining feature extracted from the work material and the product shape

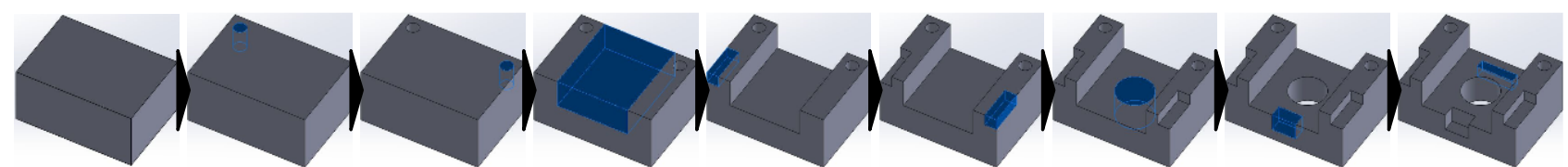

(b) Machining sequence 1

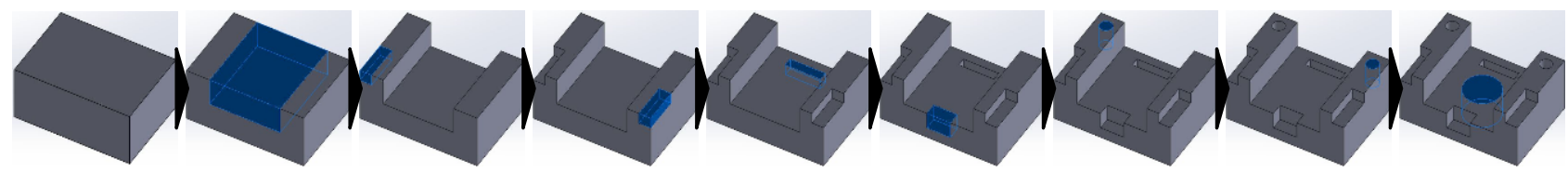

(c) Machining sequence 2

Fig. 11 Removal volume, machining feature and 2 patterns of machining sequence, the intention of which is different, of Model 2 
Table 3a Round-robin table of the machining feature obtained from the teaching in machining sequence 1

\begin{tabular}{|l|c|c|c|c|c|c|}
\hline $\begin{array}{l}\text { Open slot } \\
\text { (OS) }\end{array}$ & OS & CS & TH & OP & BH & CP \\
\hline $\begin{array}{l}\text { Closed slot } \\
\text { (CS) }\end{array}$ & - & - & - & $\triangle$ & $\times$ & - \\
\hline $\begin{array}{l}\text { Through hole } \\
\text { (TH) }\end{array}$ & - & - & & - & - & 0 \\
\hline $\begin{array}{l}\text { Open pocket } \\
\text { (OP) }\end{array}$ & $\triangle$ & - & - & & $\times$ & - \\
\hline $\begin{array}{l}\text { Blind hole } \\
\text { (BH) }\end{array}$ & $\bigcirc$ & - & - & 0 & & - \\
\hline $\begin{array}{l}\text { Closed pocket } \\
\text { (CP) }\end{array}$ & - & $\triangle$ & $\times$ & - & - & \\
\hline
\end{tabular}

Table 4a Round-robin table of the machining feature obtained from the teaching of the user in machining sequence 2

\begin{tabular}{|l|c|c|c|c|c|c|}
\hline $\begin{array}{l}\text { Open slot } \\
\text { (OS) }\end{array}$ & OS & CS & TH & OP & BH & CP \\
\hline $\begin{array}{l}\text { Closed slot } \\
\text { (CS) }\end{array}$ & - & - & - & $\Delta$ & 0 & - \\
\hline $\begin{array}{l}\text { Through hole } \\
\text { (TH) }\end{array}$ & - & $\times$ & 0 & - & 0 & $\times$ \\
\hline $\begin{array}{l}\text { Open pocket } \\
\text { (OP) }\end{array}$ & $\triangle$ & - & - & - & $\times$ & 0 \\
\hline $\begin{array}{l}\text { Blind hole } \\
\text { (BH) }\end{array}$ & $\times$ & $\times$ & 0 & $\times$ & 0 & - \\
\hline $\begin{array}{l}\text { Closed pocket } \\
\text { (CP) }\end{array}$ & - & 0 & 0 & - & 0 & \\
\hline
\end{tabular}

Table $3 \mathrm{~b}$ Score of the geometrical properties obtained from the teaching in machining sequence 1

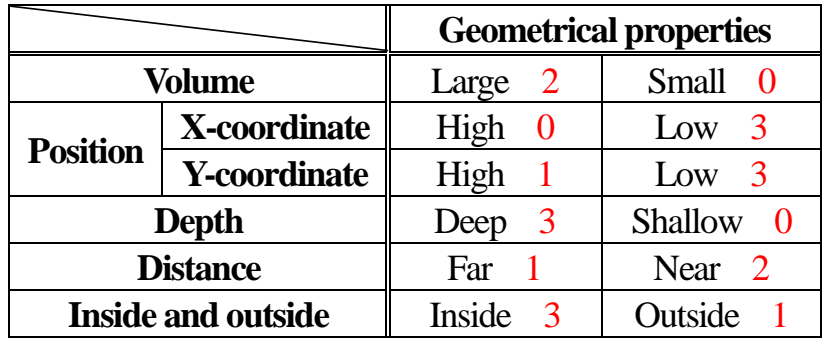

Table $4 \mathrm{~b}$ Score of the geometrical properties obtained from the teaching of the user in machining sequence 2

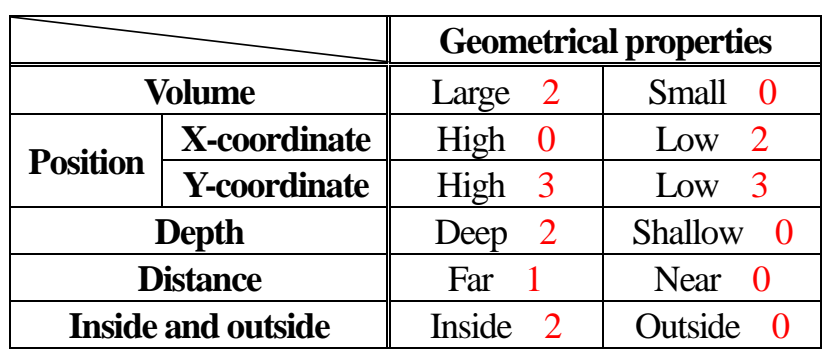

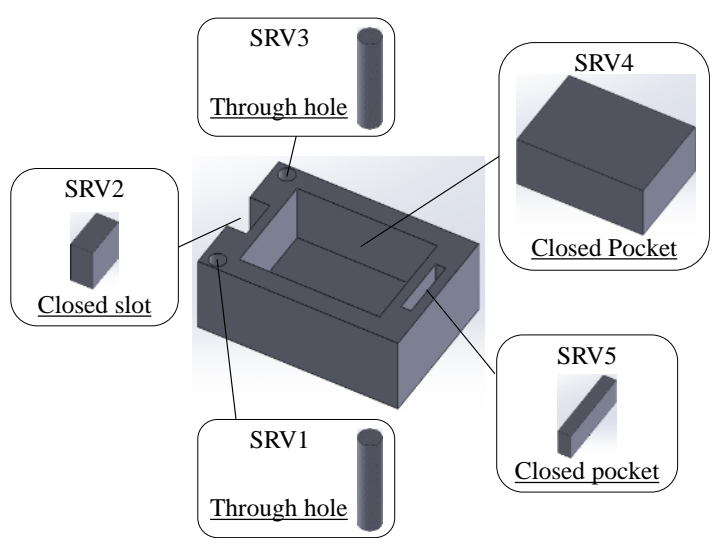

Fig.12 Split removal volume and machining feature extracted from the work material and the product shape of Model 3

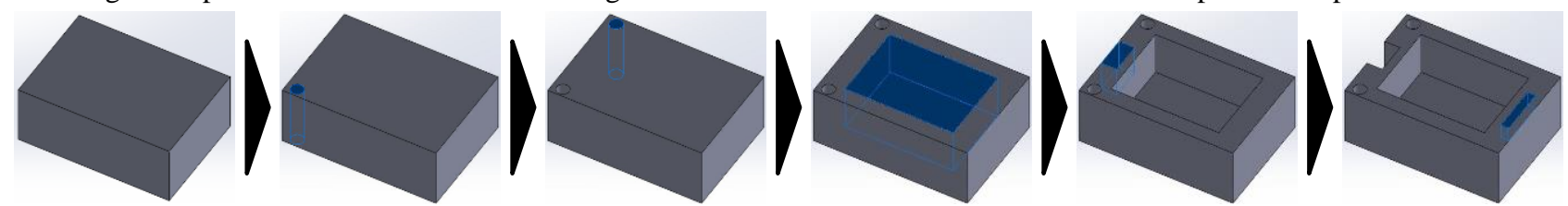

(a) Machining sequence 1

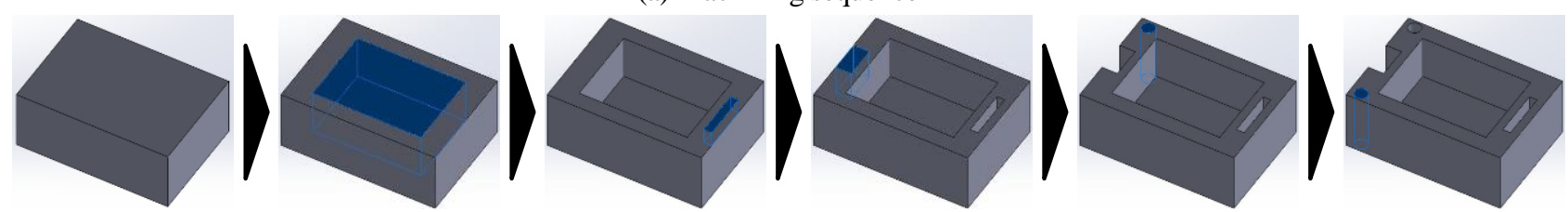

(b) Machining sequence 2

Fig.13 Machining sequence automatically determined depending on the obtained information of the machining feature and the geometrical properties. The automatically determined machining sequence matched the teaching machining sequence. 


\section{4. 結言}

本研究では，エンドミル加工の工程設計において，CAM 操作者の意図を考慮した加工順序を自動で決定する ことを目的として, CAM 操作者がシステムと対話形式にて加工順序を教示し, その操作履歴に潜む加工ノウハ ウを収集・解析し，学習した情報に基づく自動工程設計システムを開発した。開発した自動工程設計システムの 妥当性を検証するためにケーススタディを行い，加工順序を教示寸ることで得られた情報に基づいて，自動で加 工順序を決定した．自動で決定した加工順序を検証した結果，以下に示寸ことが明らかとなった.

(1) CAM 操作者がシステムと対話形式で操作を行う際に教示する情報から加工フィーチャおよび加工領域の幾 何情報における加工優先度の特徵を解析し, 蓄積することで, その CAM 操作者の加工ノウハウを学習するこ とができる.

（2）蓄積した加工優先度の情報に基づいて自動で加工順序を決定することができる. また，自動で決定した加工 順序は CAM 操作者が意図する加工順序と一致する.

本研究で開発したエンドミル加工用工程設計システムは, NC プログラム作成時に CAM 操作者の判断基準に基 づいて決定される加工順序を自動で決定するため, エンドミル加工における段取り作業の削減において有用なツ 一ルになるものと考えられる．本システムでは CAM 操作者の意図を反映した個性的な加工順序を自動で作成す ることができるので，競争力の高い機械加工を実現することができる．今後，加工除去領域が自由曲面で構成さ れているような加工フィーチャの認識が困難なモデルの解析についての検討を進める予定である.

\section{文献}

Dwijayanti, K. and Aoyama, H., Basic study on process planning for turning-milling center based on machining feature recognition, Journal of Advanced Mechanical Design, Systems and Manufacturing, Vol.8, No. 4(2014), JAMDSM0058.

El-Mehalawi, M. and Miller, R. A., A database system of mechanical components based on geometric and topological similarity. Part I: representation, Computer-Aided Design, Vol. 35, No. 1(2003a), pp.83-94.

El-Mehalawi, M. and Miller, R. A., A database system of mechanical components based on geometric and topological similarity. Part II: indexing, retrieval, matching and similarity assessment, Computer-Aided Design, Vol. 35, No. 1(2003b), pp.95-105.

濱田大地, 中本圭一, 石田 徹, 竹内芳美, 複合加工機用 CAPP システムの開発, 日本機械学会論文集 C 編, Vol.78, No.791(2012), pp.2698-2709.

井上友貴, 中本圭一, 複雑部品の切削加工に向けた工程設計支援システムのための加工フィーチャ認識手法の提 案, 日本機械学会論文集, Vol.83, No.850(2017), DOI：10.1299／transjsme. 16-00574.

Morinaga, E., Yamada, M., Wakamatsu, H. and Arai, E., Flexible process planning method for milling, International Journal of Automation Technology, Vol. 5, No. 5 (2011), pp. 700-707.

Morinaga, E., Hara, T., Joko, H., Wakamatsu, H. and Arai, E., Improvement of computational efficiency in flexible computer-aided process planning, International Journal of Automation Technology, Vol. 8, No. 3 (2014), pp. 396-405.

西田勇, 佐藤隆太, 白瀬敬一, 加工制約条件を考慮したエンドミル加工用工程設計支援システムの提案, システム 制御情報学会論文誌, Vol.30, No.3(2017), pp.81-86.

Sakurai, H. and Dave, P., Volume decomposition and feature recognition, part 1- polyhedral objects, Computer-Aided Design, Vol. 27, Issue 11 (1995), pp.793-869.

Sakurai, H. and Dave, P., Volume decomposition and feature recognition, part II- curved objects, Computer-Aided Design, Vol. 28, Issues 6-7 (1996), pp.519-537.

杉村延広，工程設計システムの現状と将来，精密工学会誌，Vol.72, No.2(2006), pp.165-170.

上野 瑛, 中本 圭一, 複合加工機用工程設計支援システムのための加工フィーチャの提案，日本機械学会論文集， Vol.81, No.825(2015), DOI : 10.1299/transjsme. 15-00108.

Wang, L., Holm, M. and Adamson, G., Embedding a process plan in function blocks for adaptive machining, CIRP Annals -Manufacturing Technology, Vol. 59, Issue 1 (2010), pp. 433-436.

Woo, Y., Wang, E., Kim, Y.S. and Rho, H.M., A hybrid feature recognizer for machining process planning systems, CIRPAnnals -Manufacturing Technology, Vol. 54, Issue 1 (2005), pp. 397-400. 


\section{References}

Dwijayanti, K. and Aoyama, H., Basic study on process planning for turning-milling center based on machining feature recognition, Journal of Advanced Mechanical Design, Systems and Manufacturing, Vol.8, No. 4(2014), JAMDSM0058.

El-Mehalawi, M. and Miller, R. A., A database system of mechanical components based on geometric and topological similarity. Part I: representation, Computer-Aided Design, Vol. 35, No. 1(2003a), pp.83-94.

El-Mehalawi, M. and Miller, R. A., A database system of mechanical components based on geometric and topological similarity. Part II: indexing, retrieval, matching and similarity assessment, Computer-Aided Design, Vol. 35, No. 1(2003b), pp.95-105.

Hamada, D., Nakamoto, K., Ishida, T. and Takeuchi, Y., Development of CAPP system for multi-tasking machine tool, Transactions of the Japan Society of Mechanical Engineers, Series C, Vol.78, No.791(2012), pp.2698-2709 (in Japanese).

Inoue, T. and Nakamoto, K., Proposal of a recognition method of machining features in computer aided process planning system for complex parts machining, Transactions of the JSME (in Japanese), Vol.83, No.850(2017), DOI : 10.1299／ transjsme. 16-00574.

Morinaga, E., Yamada, M., Wakamatsu, H. and Arai, E., Flexible process planning method for milling, International Journal of Automation Technology, Vol. 5, No. 5 (2011), pp. 700-707.

Morinaga, E., Hara, T., Joko, H., Wakamatsu, H. and Arai, E., Improvement of computational efficiency in flexible computer-aided process planning, International Journal of Automation Technology, Vol. 8, No. 3 (2014), pp. 396-405.

Nishida, I., Sato, R. and Shirase, K., Proposal of process planning system for end-milling operation considering product design constraints, The Institute of Systems, Control and Information Engineering, Vol.30, No.3(2017), pp.81-86 (in Japanese).

Sakurai, H. and Dave, P., Volume decomposition and feature recognition, part 1- polyhedral objects, Computer-Aided Design, Vol. 27, Issue 11 (1995), pp.793-869.

Sakurai, H. and Dave, P., Volume decomposition and feature recognition, part II- curved objects, Computer-Aided Design, Vol. 28, Issues 6-7 (1996), pp.519-537.

Sugimura, N., Research trends in process planning, Journal of the Japan Society for Precision Engineering, Vol.72, No. 2(2006), pp.165-170 (in Japanese).

Ueno, A. and Nakamoto, K., Proposal of machining features for CAPP system for multi-tasking machine tools, Transactions of the JSME (in Japanese), Vol.81, No.825(2015), DOI : 10.1299/transjsme. 15-00108.

Wang, L., Holm, M. and Adamson, G., Embedding a process plan in function blocks for adaptive machining, CIRP Annals -Manufacturing Technology, Vol. 59, Issue 1 (2010), pp. 433-436.

Woo, Y., Wang, E., Kim, Y.S. and Rho, H.M., A hybrid feature recognizer for machining process planning systems, CIRPAnnals -Manufacturing Technology, Vol. 54, Issue 1 (2005), pp. 397-400. 